\title{
MULTIPLE BANKING RELATIONSHIPS AND OVER-LEVERAGE IN ITALIAN MANUFACTURING FIRMS
}

\author{
by \\ Stefania Cosci and Valentina Meliciani \\ (LUMSA University of Rome and University of Teramo)
}

\begin{abstract}
The purpose of this paper is to shed more light on the determinants of the number and "type" of bank-lending relationships. In particular we investigate the determinants of the number of banking relationships and the share of the main bank for a sample of Italian manufacturing firms. The main result of the paper is that having multiple creditors increases a firm's debt capacity. We argue that this result is consistent with the view that, when banks perform transaction lending, firms borrowing from more than one creditor can increase their debt capacity by promising ex ante up to the full amount of available assets to each one of the investors.
\end{abstract}

Keywords: Multiple banking relationships, leverage

JEL classification: G21, C41 


\section{Introduction}

In the last decades several studies documented the practice of multiple borrowing in many countries but very few theoretical models addressed multiple creditors problems from an ex-ante perspective. Most of the research on banking relationships argues that establishing a close lending relationship with a bank can reduce information asymmetries and create value to the borrower, either in the form of reduced interest rate for loans and other services supplied by the bank, or as a commitment to extend loans in case of financial distress. Furthermore renegotiation of a loan in case of default is more difficult when a firm is financed by more than one bank. Why then would a firm contract with several banks? What are the most important costs and benefits of multiple banking relationships for the firm? And why would a bank accept to grant a loan to a firm that is already financed by other banks?

The aim of this paper is to investigate on the effect of multiple banking relationship on firms' leverage. Most of previous empirical studies on bank-firm relationships focused on the impact of the relationship on interest rates and they did not find univocal results. Berger and Udell (1995) report that bank-firm relationship duration has a negative impact on the loan rate, Degryse and Van Cayseele (2000) provided evidence of a positive correlation and Petersen and Rajan (1994), Elsas and Krahnen (1998) and Cosci and Meliciani (2002) report no significant correlation.

We suggest that multiple banking relationships respond to the need of firms to increase their debt capacity and is optimal for the bank when it chooses to perform transaction lending rather than invest resources on the screening activity.

In the model of Berglof, Roland and von Thadden (2004) multiple banking relationships are not the result of chance or irrationality but they are the result of an optimal contract design. Overleverage increases with multiple creditors when creditors have unilateral foreclosure rights that they can exercise in case of default, independently of what other creditors decide. If a project generates some unverifiable cash flow in addition to verifiable assets, repayment is limited by how much asset value the bank can credibly threaten to liquidate (Hart and More, 1998). With one bank, the firm commitment ability is given by the amount of verifiable assets available for foreclosure should the firm default. With more than one bank, if the firm can renegotiate individually with more than one creditor, when the firm defaults each bank has the right to foreclose the firm's assets to collect its debt. In this environment firms may chose to engage in multiple banking relationships in order to increase their debt capacity. If the firm defaults on more than one bank, the sum of claims will be larger than the available amount of verifiable assets. Bankruptcy (i.e. collective debt collection, Jackson, 1985) is an instrument to pare down individual claims that are inconsistent (Hart, 1995). 
We propose an interpretation of multiple lending relationships based on the literature focused on the difference between relationship lending and transaction lending. For the bank screening and collateral are substitute technologies. A bank may accept to grant a loan without performing any screening activity if the amount of assets of the firm is sufficiently high, i.e. if individual collection is possible and the risk of bankruptcy is low, the bank may choose to perform transaction lending and to use only public information about the firm (assets, size, localisation).

The intuition underlined by our empirical analysis is that a firm enters into multiple banking relationships in order to increase its leverage in presence of a banking system performing transaction lending. In order to test our hypothesis we first look at the determinants of the probability to engage in multiple banking relationships taking into account the simultaneous impact of various explanatory variables. We then investigate the determinants of the number of banking relationships and of the share of the main bank. Finally, we look at the relationship between the number of banking relationships and over-leverage.

We define "over-leverage" an amount of leverage that is larger than that predicted by firms' assets and we relate it with the number of banking relationships, the share of the main bank and the length of the relationship. We expect that, in transaction lending, a firm may achieve over-leverage by engaging in multiple banking relationships, while over-leverage is more difficult to achieve in relationship lending. We thus expect a positive impact of the number of banking relationships and a negative impact of the share of the main bank and the length of the relationship.

The paper is organised as follows. In the next section we discuss some evidence arising from the empirical literature on Italian multiple banking relationships. Section 3 describes the data set. Section 4 presents the econometric specification and the hypotheses to be tested. Section 5 discusses the empirical results on the determinants of the number of banking relationships. The last section draws the main conclusions of the paper.

\section{Multiple banking relationships in Italy}

In the last decade several studies have documented the strength of bank-firm relationships in the Italian banking system using micro data from various sources. The practice of multiple borrowing had already been noted decades ago by the governor of the Bank of Italy, Guido Carli, in the Annual report (Bank of Italy, 1965). This practice, according to many economists, may be justified by the presence of legal restrictions imposed by the 1936 law that impeded the direct ownership of firms by banks and, consequently, the development of close bank-firm relationships. Due mainly to the large number of banking relationships, Italy cannot be considered a bank-based system such as Germany and Japan (Cobham et al., 1999). 
Recent analyses of the phenomenon of multiple banking relationships in Italy have tried to identify the characteristics of firms engaging in multiple banking relationships by comparison with "faithful" firms. The phenomenon has been measured either by the actual number of banking relationships or by some measures of the concentration of debt.

In particular, Bianco (1997), using a sample of 30.000 firms for the period 1982-94, selected those maintaining a close and stable relationship with a bank (those characterised by a loan share of the main bank larger than $30 \%$ and stable over a period of ten years). She identified only 131 Italian firms having a close relationship with a bank, mainly small and medium sized (with less than 500 employees), and all of them having a stable relationship with a local bank or, less often, with a bank specialised in long term loans. From this study it may appear that close banking relationships in Italy are typical of small firms and small banks. However, other studies show that close relationships are not typical of Italian small firms. In fact also small firms engage in multiple relationships when they borrow from large banks. In the data set used by Detragiache et al. (2000), the number of bank relations for small and medium Italian firms is 6 for the median firm.

Another issue extensively investigated in the empirical literature is the relationship between the number of banking relationships and the cost of debt. We have seen that there are models where firms engage in multiple banking relationships in order to induce ex post competition among lenders and thus reduce the cost of debt. In general, empirical studies both in Italy and in other countries, do not find unanimous results on the impact of multiple banking relationships on the cost of debt. Bianco (1997) finds no relationship between the concentration of debt and the average borrowing cost of Italian firms. Sapienza (1997), again on a sample of Italian firms, finds that firms with closer banking relationships are characterised by a higher cost of debt. D'Auria et al. (1999) find that, other things being equal, a borrower can expect to pay each bank a slightly lower interest rate if it increases the number of banking relationships.

Few studies have looked at the link between the number of banking relationships and credit availability. Sapienza (1997) finds evidence that faithful firms are characterised by easier access to credit. This is consistent with the results of some studies from other countries (Petersen and Rajan, 1994 and 1995; Cole, 1998) but not with others (Houston and James, 1996).

Finally, other studies on multiple banking relationships in Italy have investigated the link between close bank relationships and borrowers' riskiness. Foglia et al. (1998) find that multiple banking relationships are associated with a higher riskiness of the borrowers. They argue that the parcellisation of loans substantially weakens the discipline exercised by the banks and makes corporate borrowers more fragile. Ferri and Messori (2000) show that relationship oriented lenders have a ratio of bad loans lower than the average. Using a sample of 208 banks, they conclude that 
Italian banks with strong relationships have a significantly lower ratio of bad and doubtful loans than the average of the universe. This evidence suggests that firms might be able to have access to credit with little screening effort by borrowing from several banks.

\section{The Data Set}

The data set used in this paper consists of information from a survey on Italian manufacturing firms and balance sheet data from the same set of firms. The survey conducted by Capitalia for the years 1998-2000 is characterised by a very rich set of qualitative information on firms' employment, internationalisation, investment activity, innovation, market position, and finance. The whole sample consists of 4021 firms (covering a share of $9.2 \%$ in terms of employment and $9.9 \%$ in terms of value added with respect to the national data) that is reduced to 2612 once we exclude missing and contradictory data.

This rich set of information has allowed us to study the determinants of the number of banking relationships and its link with leverage controlling for several characteristics of the firms. Moreover, differently from a previous study (Cosci and Meliciani, 2002) we had the possibility to match the information on the number of banking relationships with that on the share of the main bank.

The sample of firms has relationships from a minimum of one bank to a maximum of 35 banks with an average of 5.7 relationships and a median of 5 relationships. The minimum share of the main bank is $5 \%$, the maximum 100 , the average 44.4 and the median 40 . Finally the correlation coefficient between the number of banking relationships and the share of the main bank is -0.50 (see table 3.1).

Table 3.1 Number of banking relationships and share of the main bank

\begin{tabular}{|l|l|l|}
\hline $\begin{array}{l}\text { Correlation (1) } \\
(2)=-0.50\end{array}$ & $\begin{array}{l}(1) \text { Number of } \\
\text { banking relations }\end{array}$ & (2) Share of main bank \\
\hline Mean & 5.7 & 44.4 \\
Minimum & 1 & 5 \\
Maximum & 35 & 100 \\
Percentiles: & & 15 \\
5 & 2 & 30 \\
25 & 3 & 40 \\
50 & 5 & 60 \\
75 & 7 & 80 \\
90 & 10 & 100 \\
99 & 20 &
\end{tabular}


The degree of negative correlation between the number of banking relationships and the share of the main bank is not as high as one may expect suggesting that we can construct different typologies of firms. In particular, after having defined as "multiple bank borrowers" those firms with more than 4 banking relationships we distinguish between "multiple bank borrowers with a main bank" (Multi/main) and without a main bank (Multi). The first category includes multiple bank borrowers for which the share of the main bank is larger than 49 and the second category those firms for which it is smaller then $50 \%$. Also between firms with few relationships we distinguish between "local firms" (No-Multi/local) and other firms (No-Multi). Local firms are defined as those firms with less than 5 banking relationships, a share of the main bank larger than $49 \%$, and with the main bank being localised in the same geographical area (provincia) of the firm. Table 3.2 reports the characteristics of the four typologies of firms by firm size (small: less than 50 employees, medium and large: more than 50 employees).

Table 3.2 The characteristics of multiple-bank relationships firms by size

\begin{tabular}{|c|c|c|c|c|c|c|c|c|c|c|}
\hline & $\begin{array}{l}\text { Emplo- } \\
\text { yees }\end{array}$ & Sales & $\begin{array}{l}\text { Leve- } \\
\text { rage }\end{array}$ & Age & $\begin{array}{l}\text { Innova- } \\
\text { tion }\end{array}$ & R\&D & South & $\begin{array}{l}\text { Credit } \\
\text { rationi } \\
\mathrm{ng}\end{array}$ & $\begin{array}{l}\text { Earnings/ne } \\
\text { t capital }\end{array}$ & $\begin{array}{l}\text { Cost } \\
\text { of debt }\end{array}$ \\
\hline Small firms & & & & & & & & & & \\
\hline Multi/main (200) & 25.22 & 5774.07 & 0.49 & 29.07 & 0.54 & 0.38 & 0.12 & 0.22 & 0.15 & 0.050 \\
\hline Multi (791) & 25.18 & 5815.27 & 0.50 & 26.80 & 0.55 & 0.39 & 0.14 & 0.25 & 0.28 & 0.047 \\
\hline Non- Multi/Local (476) & 19.88 & 3211.15 & 0.31 & 26.98 & 0.53 & 0.27 & 0.16 & 0.26 & 0.15 & 0.038 \\
\hline $\begin{array}{l}\text { Non-Multi (594) } \\
\text { Large and medium firms }\end{array}$ & 20.77 & 3673.06 & 0.35 & 26.32 & 0.49 & 0.32 & 0.19 & 0.23 & 0.02 & 0.041 \\
\hline Multi/main (81) & 186.53 & 39131.3 & 0.67 & 31.57 & 0.76 & 0.63 & 0.13 & 0.20 & 0.22 & 0.041 \\
\hline Multi (352) & 251.46 & 56220.63 & 0.72 & 34.85 & 0.75 & 0.66 & 0.10 & 0.16 & 0.23 & 0.047 \\
\hline Non-Multi/Local (41) & 171.22 & 29439.5 & 0.58 & 37.07 & 0.68 & 0.55 & 0.19 & 0.24 & 0.14 & 0.047 \\
\hline Non-Multi (58) & 229.60 & 37104.84 & 0.68 & 30.79 & 0.70 & 0.49 & 0.21 & 0.21 & 0.28 & 0.048 \\
\hline
\end{tabular}

We can observe that the sample includes a larger proportion of small firms than medium and large firms. In general small firms tend to be younger, less innovative, and tend to have a lower leverage with respect to medium and large firms. Among small firms the sample is more or less equally distributed between multiple and no-multiple bank borrowers (there are 991 multiple lenders and 1070 single lenders). Multiple bank borrowers tend to have higher sales, a higher leverage and to do more R\&D with respect to those having few lenders. Among multiple bank borrowers, firms with a main bank tend to be older and to have lower profits, they also tend to have 
a higher cost of debt while they feel less rationed. Among non-multiple bank borrowers local firms tend to have a lower leverage and to feel more rationed while they appear to have a lower cost of debt. With respect to innovation they tend to be more innovative but to spend less on R\&D with respect to other non-multiple lenders.

Among medium and large firms the majority are multiple bank borrowers (about 80\%). Also in this sample multiple bank borrowers have higher sales and spend more on R\&D than non-multiple bank borrowers, however the difference in leverage is much less pronounced than in the case of small firms (for these firms multiple bank borrowers without a main bank have the higher leverage followed by other multiple bank borrowers and non-multiple bank borrowers while local bank borrowers have again the lowest level of leverage).

In general multiple lenders appear to be more innovative and to have a higher leverage (for large firms this is true only for multiple lenders without a main bank) than non-multiple lenders. In what follows the econometric analysis will help to single out the simultaneous impact of different factors affecting the number of banking relationships and the share of the main bank. In particular we will be interested in looking at the robustness of the positive correlation between leverage and multiple banking relationships and to suggest possible interpretations of this result.

\section{The hypotheses tested and the econometric specification}

We first look at the determinants of the probability to engage in multiple banking relationships taking into account the simultaneous impact of various explanatory variables. We then investigate the determinants of the number of banking relationships and the share of the main bank. Finally, we look at the relationship between the number of banking relationships and over-leverage.

We define as multiple banking relationships those firms having more than four banking relationships and we ask what factors affect the probability of engaging in multiple banking relationships. Here the dependent variable is a binary variable, assuming the value of one for firms with more than seven banking relationships and zero for the other firms. The econometric model for a binary dependent variable is the following:

$$
\begin{aligned}
& \operatorname{Prob}(Y=1)=F\left(\boldsymbol{\beta}^{\prime} \boldsymbol{x}\right) \\
& \operatorname{Prob}(Y=0)=1-F\left(\boldsymbol{\beta}^{\prime} \boldsymbol{x}\right)
\end{aligned}
$$

Where $Y=1$ for firms with more than seven banking relationships and zero otherwise; $\mathbf{x}$ is a matrix of explanatory variables, and the set of parameters $\beta$ reflects the impact of changes in $\mathbf{x}$ on the probability. We estimate (1) using a probit model. 
We expect the probability of engaging in multiple banking relationship to depend on various variables describing firms' characteristics (being a co-operative: $C O$ and being innovative: INNO), their size $(S I Z E)$ and age $(A G E)$. In particular other studies have found the number of banking relationships to grow with firms' size and age (Ongena and Smith, 2000; Harhoff and Körting, 1998b; Cosci and Meliciani, 2002). We expect co-operatives to have a lower number of banking relationships since they tend to borrow from local banks and to perform relationship banking (Ferri and Messori, 2000). The relationship between firms' innovation and the number of banking relationships could be negative because of information dissemination problems (Bhattacharya and Chiesa, 1995). On the other hand it could be positive if firms with long-term investment opportunities want to have multiple informed creditors because the commitment to provide finance in the long run is not binding (Hellwig, 1991), or if banks prefer to share the risk of innovative projects with other banks. Previous empirical studies have found that firms belonging to high tech sectors have a higher probability to engage in multiple banking relationships (Cosci and Meliciani, 2002).

Together with these variables we consider the cost of debt (ONFIN), a variable indicating whether a firm feels to be credit rationed (DESCRED), innovation (INNO) and total leverage (LEVERAGE). The rationale for including the cost of debt and credit rationing derives from the main theoretical justifications of multiple banking relationships. Multiple lenders could pay a lower interest rate by inducing ex-post competition among lenders (Rajan, 1992) or a higher interest rate because monitoring costs are higher (Berglof, 1990). They could be more credit rationed if close bank-firm relationships favour an efficient exchange of information (Petersen and Rajan, 1995) or less rationed if single lenders face liquidity problems due to the behaviour of the bank (Detragiache et al, 2000).

Finally total leverage was found to be significant in explaining both the probability to engage in multiple banking relationships and the number of banking relationships (Cosci and Meliciani, 2002). Here we want to test whether this result still holds on a larger sample of firms and controlling for a larger set of explanatory variables and we want to shed more light on the interpretation of this finding.

Since we have data on the number of banking relationships by firm we also directly estimate the impact of various factors on this number. Here the dependent variable has a discrete nature. The statistical models generally applied for estimating equations where the dependent variable has a discrete nature are applications and generalisations of the Poisson distribution (Hausman et al., 1984). The Poisson probability function may be expressed as follows: 


$$
P(n)=\exp (-\lambda) \lambda n / n !
$$

where $n$ is the number of occurrences of the event and $\lambda$ is the mean and the variance of the distribution. If we specify $n$ as the number of banks, we can make the parameter $\lambda$ depend on a set of explanatory variables that we assume to affect the number of banking relationships:

$$
\lambda_{i}=e^{\beta X_{i}}
$$

The coefficients can be estimated maximising the log-likelihood function of the Poisson model.

The main problem of the Poisson specification is that it imposes equality between the mean and the variance of the distribution. When this hypothesis is rejected by the data, i.e. the case of "overdispersion", the Poisson model is inappropriate as it leads to an underestimation of the variance-covariance matrix. The negative binomial model is an extension of the Poisson model that allows the variance of the distribution to increase faster than the mean (Cameron and Trivedi, 1986). This model arises by specifying:

$$
\ln \lambda_{i}=\beta X_{i}+\varepsilon_{i}
$$

where $\exp (\varepsilon)$ has a gamma distribution with mean one and variance $\alpha$. A natural form of overdispersion is the following:

$$
\operatorname{var}(n) / E(n)=1+\alpha E(n)
$$

where the Poisson model results from setting $\alpha=0$. We therefore estimate a negative binomial model if $\alpha$ is not significantly different from zero. Here the explanatory variables are firms' size, age, being a co-operative, being innovative, being located in the South and total leverage ${ }^{1}$.

The determinants of the number of banking relationships may partially coincide but also differ with respect to the determinants of the share of the main bank. We thus also estimate the determinants of the share of the main bank, considering the same explanatory variables plus a variable indicating whether the firm performs her financial operations internally or delegates them to a financial intermediary (INFIN).

\footnotetext{
${ }^{1}$ We do not include the cost of debt and firms' perception to be credit rationed since they were not significant while we include the dummy for the South of Italy that was not significant in explaining the probability to engage in multiple banking relationships.
} 
The last model estimated investigates the relationship between "over-leverage" and the number and type of banking relationships. In particular we define "over-leverage" an amount of leverage that is larger than that predicted by firms' assets (the residual of a regression of total debt on total assets) and we relate it with the number of banking relationships, the share of the main bank and the length of the relationship. We expect that, in transaction lending, a firm may achieve "overleverage" by engaging in multiple banking relationships. This is because the firm can promise ex ante up to the full amount of available assets to each one of the creditors, while each investor has the right to foreclose on the firm's assets to collect her debt (von Thadden, Berglof and Roland, 2004). On the other hand, over-leverage, is more difficult to achieve in relationship lending. We thus expect a positive impact of the number of banking relationships ( $N B A N)$ and a negative impact of the share of the main bank (MSHA) and the length of the relationship (LEN).

In order to capture the link between over-leverage and bank-firm lending relationships we have to take into account also other variables that can affect firms' demand for leverage and banks' willingness to provide leverage. We thus control for firms' size, age, return on investment (ROI), growth $(G R O W)$, cost of debt and geographical location and innovation:

$\operatorname{DEBT}_{i}=\alpha_{0}+\alpha_{1} \operatorname{ASSETS}_{i}+U_{i}$

$U_{i}=\beta_{0}+\beta_{1} C O S T_{i}+\beta_{2} R O I_{i}+\beta_{3} S I Z E_{i}+\beta_{4} A G E+\beta_{5} N B A N+\beta_{6} M S H A+\beta_{7} L E N+\beta_{8} S O U T H+\beta_{9} G R O W+E_{i}$

Most of the included variables are standard in the literature (Sapienza, 1997; Rajan and Zingales, 1995). In particular the cost of debt is expected to have a negative impact on the demand for leverage. Firms' earnings are also expected to have a negative impact on the demand for leverage because managers prefer to finance their investment with internal revenues, while growth is expected to have a positive impact. Size and age can be proxies for the information outside investors have, which should increase their preference for equity relative to debt. 


\section{Empirical Results}

The results reported in table 5.1 show that the larger is firms' leverage the larger is the probability of engaging in multiple banking relationships. Innovative firms have a higher probability to engage in multiple banking relationships and the size and the age of the firm affect positively the probability of engaging in multiple banking relationships. Finally the probability is lower for co-operative firms, that in Italy are traditionally financed by co-operative banks with whom they establish long-term close banking relationships.

Interestingly the probability to engage in multiple banking relationships is not significantly associated with neither the cost of debt nor firms' perceptions to be credit rationed. It appears that these two factors cannot explain the practice of multiple lending.

This is not surprising considering that theoretical models based on ex post competition among lenders or the fear of the firm to be denied credit by the banking system when the main bank faces liquidity problems can justify the choice to go to few banks but not the high number of banking relationships documented by the empirical literature.

Table 5.1: The determinants of the probability to engage in multiple banking relationships

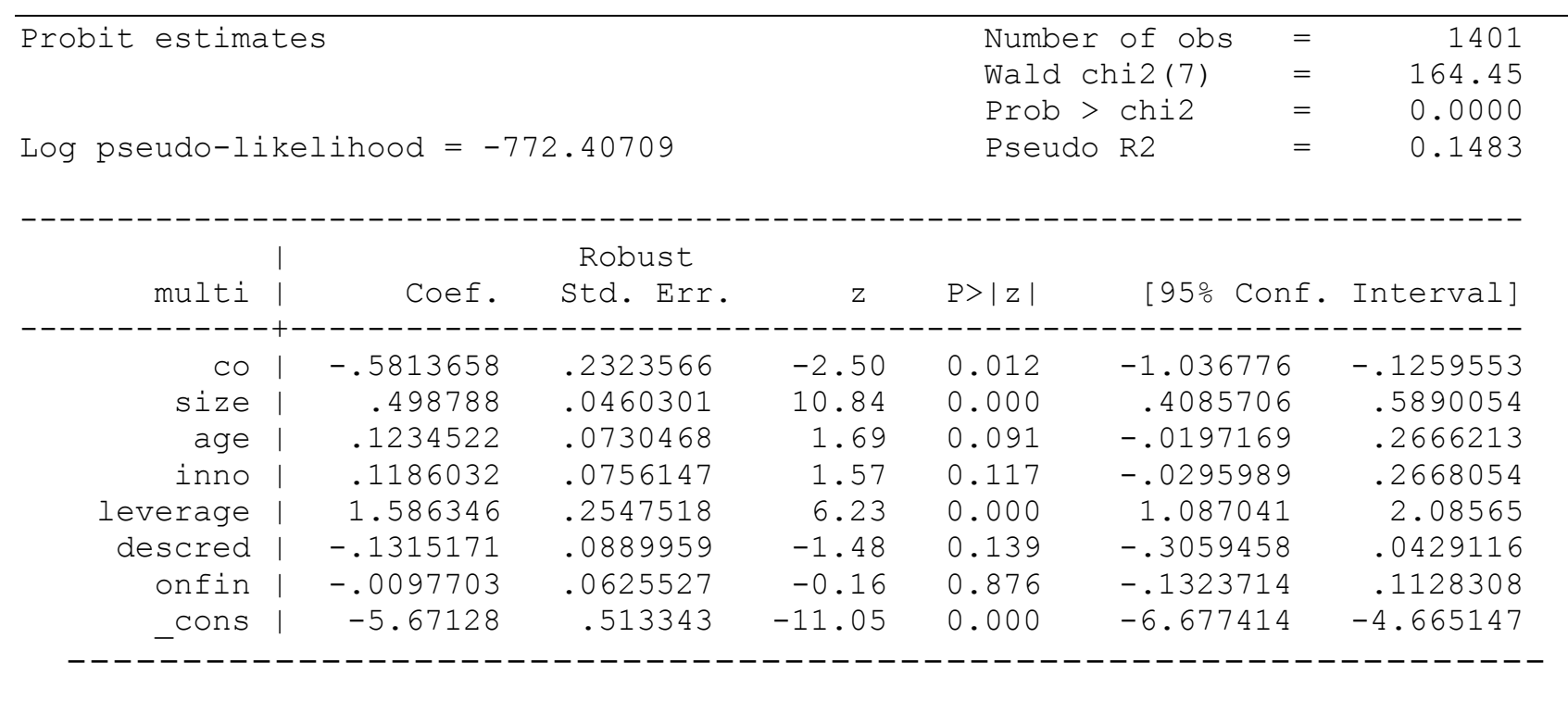

Consistently with the results of the probit estimation we find that the number of banks per firm is positively affected by total leverage, the size of the firm and the fact of being innovative while it is negatively affected by being a co-operative (table 5.2). Moreover we also find a negative coefficient for firms located in the South of Italy. This is in line with Ferri and Messori (2000). The lower number of banks in the South can also be justified considering that, in order for the bank to find it 
optimal to perform transaction lending, it must perceive that the risk of bankruptcy is sufficiently low and this is less likely to happen for firms operating in the less developed part of Italy.

When looking at the determinants of the share of the main bank (table 5.3) we find it to be positively (or negatively) influenced by some of the variables influencing negatively (or positively) the number of banking relationships (size, being a co-operative and total leverage). However innovation and geographic localisation only affect the number of banking relationships and not the share of the main bank. Finally firms that use internal resources (rather than intermediaries) to manage their financial operations have a lower share of credit with a main bank.

In general the various specifications suggest that there is a robust positive association between total leverage and the dispersion of credit among lenders. This is consistent with the view that firms chose to engage in multiple banking relationships in order to increase their debt capacity. If a project generates some unverifiable cash flow in addition to verifiable assets, repayment is limited by how much asset value the bank can credibly threaten to liquidate (Hart and More, 1998). With one bank, the firm commitment ability is given by the amount of verifiable assets available for foreclosure should the firm default. With more than one bank, if the firm can renegotiate individually with more than one creditor, when the firm defaults each bank has the right to foreclose the firm's assets to collect its debt.

\section{Table 5.2: The determinants of the number of banking relationships}

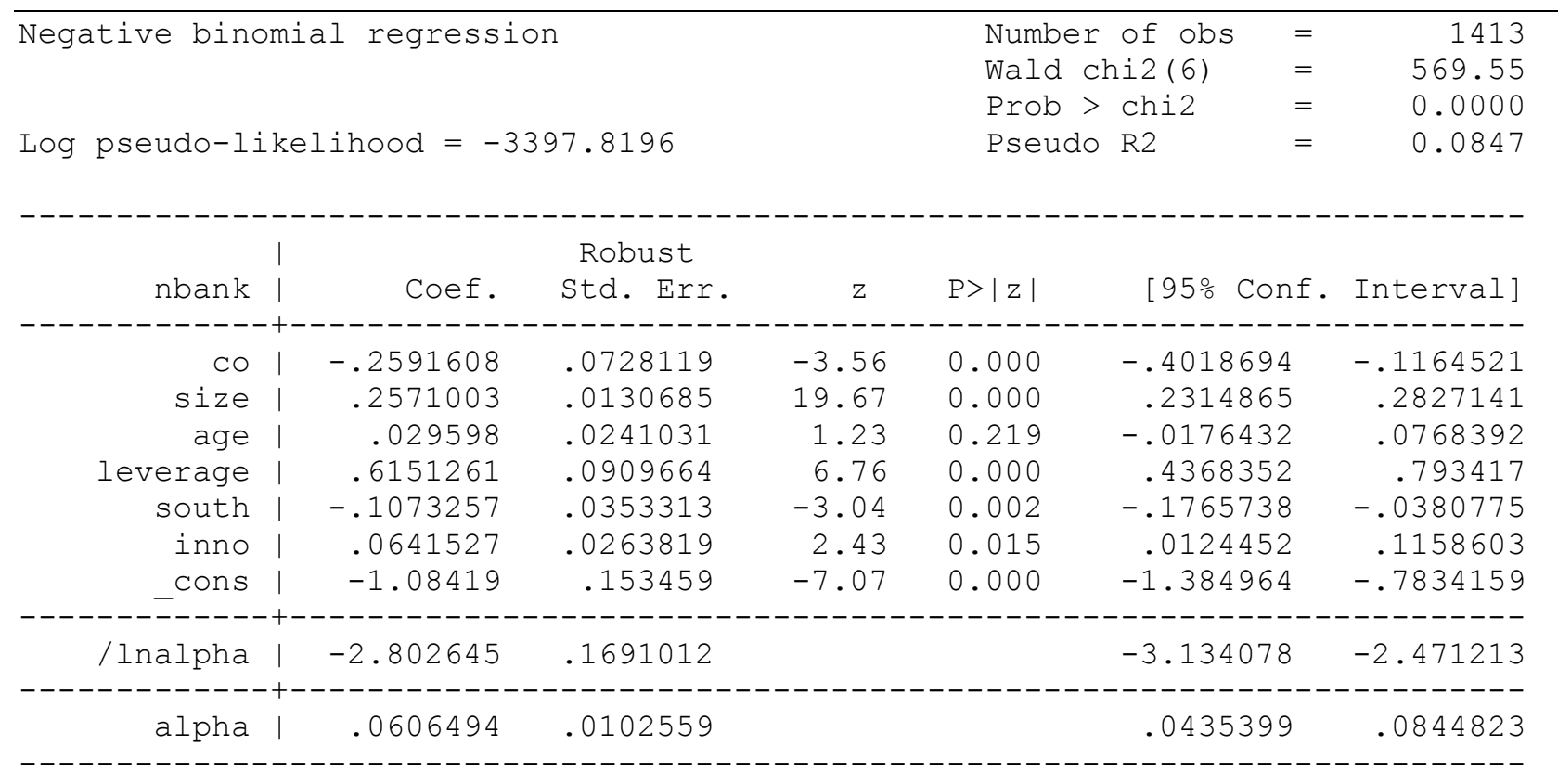


Table 5.3: The determinants of the share of the main bank

\begin{tabular}{llr}
\hline Regression with robust standard errors & Number of obs $=1412$ \\
& F $(7,1404)=21.76$ \\
& Prob $>$ F & 0.0000 \\
& R-squared & 0.1020 \\
& Root MSE & $=51754$
\end{tabular}

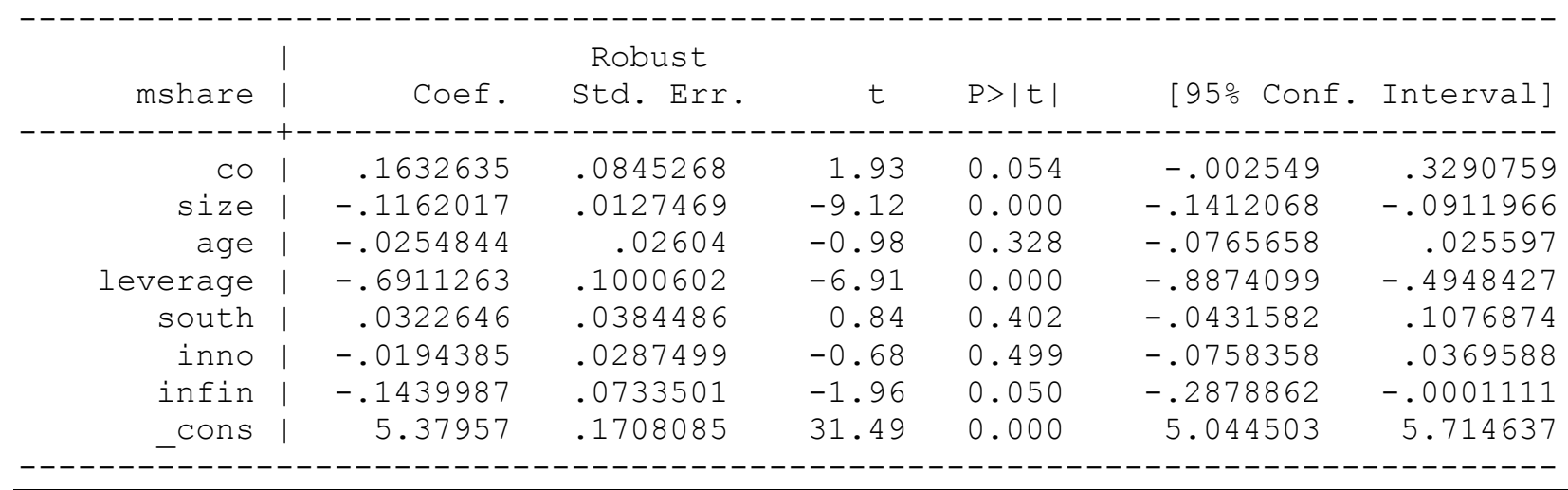

Table 5.4 looks at the relationship between over(under) leverage and the type and number of banking relationships. In particular we expect that firms can achieve a level of debt above what expected by their level of assets (controlling for the factors affecting the demand for leverage) by performing transaction lending and by increasing the number of banking relationships.

As expected the residual of a regression of total debt on total assets is positively influenced by the number of banking relationships, and negatively by the share of the main bank and the length of the relationship. Variables affecting the choice of debt for a given amount of assets on the demand side are significant with the expected sign. Leverage decreases with the variables that are positively related with the self-financing capacity of the firm such as size, age and return on investment. Leverage demand is higher for growing firms and lower the higher is the cost of debt. Finally firms located in the South of Italy are characterised by a lower level of leverage. This result suggests that, when the risk of bankruptcy is higher, firms may find too risky to perform transaction lending.

Table 5.4: The relationship between total assets and total debt and the determinants of "over(under) leverage"

\begin{tabular}{|c|c|c|c|c|c|c|}
\hline Regression with & robust star & dard errors & & & $\begin{array}{l}\text { Number of obs } \\
\text { F( 1, 1425) } \\
\text { Prob > F } \\
\text { R-squared } \\
\text { Root MSE }\end{array}$ & $\begin{array}{l}=1427 \\
=50653.42 \\
=\quad 0.0000 \\
=\quad 0.9684 \\
=\quad .21596\end{array}$ \\
\hline debt | & Coef. & $\begin{array}{l}\text { Robust } \\
\text { Std. Err. }\end{array}$ & t & $P>|t|$ & [95\% Conf. & Interval] \\
\hline $\begin{array}{r}\text { assets } \\
\text { _cons }\end{array}$ & $\begin{array}{r}.9769402 \\
-.0733977\end{array}$ & $\begin{array}{l}.0043407 \\
.0390254\end{array}$ & $\begin{array}{r}225.06 \\
-1.88\end{array}$ & $\begin{array}{l}0.000 \\
0.060\end{array}$ & $\begin{array}{r}.9684253 \\
-.149951\end{array}$ & $\begin{array}{l}.9854552 \\
.0031557\end{array}$ \\
\hline
\end{tabular}




\begin{tabular}{|c|c|c|c|c|c|c|c|}
\hline overdebt & 1 & Coef & $\begin{array}{l}\text { Robust } \\
\text { Std. Err. }\end{array}$ & t & $P>|t|$ & {$[95 \% \mathrm{Cc}$} & Interval ] \\
\hline & + & -- & 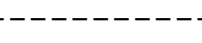 & & & & . \\
\hline nban & 1 & .0060204 & .0019718 & 3.05 & 0.002 & .0021523 & .0098884 \\
\hline south & 1 & -.1057584 & .0178722 & -5.92 & 0.000 & -.1408172 & -.0706996 \\
\hline length & 1 & -.0009 & .0005083 & -1.77 & 0.077 & -.0018971 & .0000971 \\
\hline mshare & | & -.0013889 & .0003279 & -4.24 & 0.000 & -.0020322 & -.0007456 \\
\hline size & 1 & -.0112814 & .0058381 & -1.93 & 0.054 & -.0227335 & .0001708 \\
\hline roi & | & -.0362771 & .0149459 & -2.43 & 0.015 & -.0655955 & -.0069587 \\
\hline age & | & -.0283554 & .0104395 & -2.72 & 0.007 & -.048834 & -.0078768 \\
\hline grow & 1 & .0373787 & .017983 & 2.08 & 0.038 & .0021026 & .0726549 \\
\hline onfin & | & -.0253051 & .0118736 & -2.13 & 0.033 & -.0485968 & -.0020134 \\
\hline _cons & | & .2493014 & .0525263 & 4.75 & 0.000 & .1462637 & .3523391 \\
\hline
\end{tabular}

\section{Conclusions}

This paper has looked at the determinants of the number of banking relationships and the share of the main bank in Italian manufacturing firms. We have found that multiple lenders are characterised by higher leverage while firms with a high share of the main bank tend to have a lower leverage. On the other hand we find no relationship between the probability to engage in multiple banking relationships and the cost of credit or firms' perception to be credit rationed.

These results call for an explanation of the multiple banking relationship puzzle that stresses the fact that having multiple creditors increases a firm's debt capacity. In a previous paper (Cosci and Meliciani, 2002) we have proposed some explanations based on the behaviour of the bank (risk sharing and the willingness of banks to provide many (small) loans in order to increase the number of customers for cross-selling). In this paper we have suggested that multiple banking relationships can be the result of an optimal contract design. Over-leverage increases with multiple creditors when creditors have unilateral foreclosure rights that they can exercise in case of default, independently of what other creditors decide.

Further empirical analyses should try to discriminate between different explanations of the relationship between leverage and the practice of multiple lending relationships by looking at how various variables reflecting firms' risk of bankruptcy affect the association between leverage and the number of creditors. More insights could also be gained by testing the relationship for subsamples of firms of different size, sector and geographical area. Finally it would be interesting to extend the analysis to other countries to see whether the link between leverage and the number of lending relationships is typical of the Italian banking (and industrial) system or is a general feature. 


\section{REFERENCES}

Bank of Italy (1965). Annual Report for the year 1964, Rome.

Bianco, M. (1997). "Vincoli finanziari e scelte reali delle imprese italiane: Gli effetti di una relazione stabile con una banca" in Angeloni, I:, Conti, V. Passacantando, F. (Eds), Le banche e il finanziamento delle imprese, Il Mulino, Bologna.

Boot, A.W.A and Thakor, A.V. (2000). “Can Relationship Banking Survive Competition?”, Journal of Finance, Vol. 55, pp. 679-713.

Boyd, J. and Prescott, E. (1986). "Financial Intermediary Coalitions", Journal of Economic Theory, Vol. 38, pp. 211-232.

Brealey, R.A. and Myers, S.C. (2000). Principles of Corporate Finance, Irwin/McGraw-Hill.

Cameron, A. and Trivedi, K. (1986). Econometric Models Based on Count Data: Comparisons and Applications of some Estimators and Tests, Journal of Applied Econometrics, Vol. 1, pp. 2953.

Cobham, D., Cosci, S. and Mattesini, F. (1999). "The Italian Financial System: Neither Bank-based Nor Market-based”, Manchester School, Vol. 67, pp. 325-345.

Cole, R. (1998). "The Importance of Relationships to the Availability of Credit", Journal of Banking and Finance, Vol. 22, pp. 959-977.

Cornell, B. and Shapiro, A.C. (1988). "Financing Corporate Growth", Journal of Applied Corporate Finance, Vol. 1, pp. 6-22.

Cosci, S. and Mattesini, F. (1997). "Credito e sviluppo nelle province italiane”, in a cura di F. Cesarini, G., Ferri e M., Giardini, Credito e sviluppo 2 Il Mulino.

Cosci, S. and Meliciani, V. (2000). The Role of Screening and Scope Economies in Relationship Lending, Quaderni ISE n.116, LUISS, Rome.

Cosci, S. and Meliciani, V. (2002). Multiple banking relationships. Evidence from the Italian experience, The Manchester School Supplement, pp. 37-54.

D’Auria, C., Foglia, A., Marullo Reedtz, P. (1999). "Bank Interest rates and Credit Relationships in Italy", Journal of Banking and Finance, Vol.23, pp.1067-1093.

Degryse, H. and Van Cayseele, P. (2000). "Relationship Lending within a Bank-based System: Evidence from European Small Business Data”. Journal of Financial Intermediation, Vol. 9, pp. 90-109.

Detragiache, E., Garella, P. and Guiso, L. (2000). "Multiple versus Single Banking Relationships: Theory and Evidence", Journal of Finance, Vol. 55, pp. 1133-61.

Dewatripont, D. and Maskin, E. (1991). "Credit and Efficiency in Centralised and Decentralised Economies", Review of Economic Studies, Vol. 62, pp. 541-55. 
Farinha, L.A. and Santos, J.A.C. (2000). Switching from Single to Multiple Bank Lending Relationships: Determinants and Implications, Mimeo.

Foglia, A., Laviola, S. and Marullo Reedtz, P. (1998). "Multiple Banking Relationships and the Fragility of Corporate Borrowers", Journal of Banking and Finance, Vol. 22, pp. 1441-56.

Ferri, G. and Messori, M. (2000). "Bank-Firm Relationship and Allocative Efficiency in Northeastern and Central Italy and in the South”, Journal of Banking and Finance, Vol. 24, pp. 1067-95.

Harhoff, D. (1999). "The Relationship Between SMEs and Banks in Germany. A Summary of Empirical Results", Rassegna Economica, Vol. 63, pp. 63-89.

Harhoff, D. and Korting, T. (1998). "Lending Relationships in Germany Empirical: Results from Survey Data", Journal of Banking and Finance, Vol. 22, pp. 1317-53.

Hausman, J., Hall, B. H. and Griliches, Z. (1984). "Econometric Models for Count Data with an Application to the Patents-R\&D Relationship", Econometrica, Vol. 52, pp. 909-937.

Houston, J. and James, C. (1996). "Bank Information Monopolies and the Mix of Public and Private Debt Claims", Journal of Finance, Vol. 51, 1863-89.

Machauer, A. and Weber, M. (1998). "Bank Behaviour on Internal Credit Ratings of Borrowers", Journal of Banking and Finance, Vol. 22, pp. 1355-83.

Onado, M. (1999). “Sistemi creditizi e sviluppo delle PMI”, Rassegna economica, Vol. 63, pp. 12330.

Ongena, S. and Smith, D.C. (2000). "What Determines the Number of Banking Relationships? Cross-Country Evidence”, Journal of Financial Intermediation, Vol. 9, pp. 27-55.

Petersen, M. and Rajan, R.G. (1994). "The Benefits of Lending Relationship: Evidence from Small Business Data", The Journal of Finance, Vol. 49, pp. 3-37.

Petersen, M. and Rajan, R.G. (1995). “The Effect of Credit Market Competition on Lending Relationships", Quarterly Journal of Economics, Vol. 90, pp. 407-444.

Rajan, R.G. (1992). “Insiders and Outsiders: the Choice between Informed and Arm's-Length Debt", Journal of Finance, Vol. 47, pp. 1367-1400.

Sapienza, P. (1997). "Le scelte di finanziamento delle imprese italiane", in Angeloni, I:, Conti, V. Passacantando, F. (Eds), Le banche e il finanziamento delle imprese, Il Mulino, Bologna.

Sharpe, S. (1990). “Asymmetric Information, Bank Lending and Implicit Contracts: A Stylized Model of Customer Relationships", Journal of Finance, Vol. 45, pp. 1069-1087.

von Thadden, E. L. (1995). "Long-Term Contracts, Short-Term Investment, and Monitoring”, Review of Economic Studies, Vol. 62, pp. 557-75. 
Von Thadden, E. L., Berglof, E. and G. Roland (2003), "Optimal debt design and the role of bankruptcy", working paper.

Thakor, A.V. (1996). "Capital Requirements, Monetary Policy, and Aggregate Bank Lending: Theory and Empirical Evidence”, Journal of Finance Vol. 51, pp. 279-324.

Williamson, S. (1986). "Costly Monitoring, Financial Intermediation, and Equilibrium Credit Rationing", Journal of Monetary Economy, Vol. 18, pp. 159-79.

Winton, A. (1995). "Delegated Monitoring and Bank Structure in a Finite Economy”, Journal of Financial Intermediation, Vol. 4, pp. 158-87. 